\title{
Linking Organizational Identification to Job Embeddedness in Indian Context: Role of Job Satisfaction and Perceived Organizational Support
}

\author{
Sumit Kumar Ghosh ${ }^{1}$ \\ ${ }^{1}$ Faculty at Indian Institute of Management Indore, India \\ Correspondence: Sumit Kumar Ghosh, E-mail: skghosh9999@rediffmail.com
}

Received: September 28, 2015

Accepted: October 21, 2015

Online Published: November 25, 2015

doi:10.5539/ijbm.v10n12p258

URL: http://dx.doi.org/10.5539/ijbm.v10n12p258

\begin{abstract}
The study was undertaken to link organizational identification with job embeddedness in Indian context. Literature review suggested that though there is a case for linking these two variables there are hardly any study which has empirically tried to explore this relationship particularly in Indian context. For addressing this gap in the literature, a survey was conducted using established scales. In all 325 usable survey responses from executives working in various sectors in India were analyzed using regression analysis. The results show that organizational identification and job embeddedness are strongly related. However, hypotheses stating that the perceived organizational support and job satisfaction will accentuate this relationship were not supported. These findings along with the finding that organizational identification and job embeddedness are strongly related, throws up a few implications for the practicing managers. Overall this study attempts to contribute to the literature by empirically examining the relationship between organizational identification and job embeddedness as the existing literature on this relationship is scant. Moreover, the context of the study being India, the findings of the study will contribute to the implications for practicing managers in India for arresting employee turnover.
\end{abstract}

Keywords: job embeddedness, organizational identification, job satisfaction, perceived organizational support, India

\section{Introduction}

According to a survey (Note 1) the employee turnover in India is poised to be very high as the economic growth is picking up. Organizations have to gear up to meet this challenge of reducing employee turnover. Turnover literature suggests that an individual's turnover behavior depends on his/her desire to stay with the organization and/or availability of alternate opportunities elsewhere (March \& Simon, 1958). Quite a few research studies have positively linked an individual's desire to leave an organization and/or actual turnover with job attitudes such as job satisfaction and organizational commitment, (Chen et al., 2011; Griffeth, 2000). Also studies have linked Leader Member Exchange, Human Resource practices etc. to an individual's desire to stay with an organization (Bauer, 2006; Jiang et al., 2012). Employability, job search behavior etc. (De Cuyper et al., 2011; Direnzo \& Greenhaus, 2011) were found to be related with intention to stay or leave an organization. Mitchell et al. (2001) introduced the concept of Job-embeddedness and argued that it can predict turnover intention beyond work attitudes. Subsequently number of studies, under the premise of social exchange theory, (Blau, 1964), have linked commitment (Hom et al., 2009) and other variables such as, organization based self-esteem ,leader member exchange , (Sekiguchi, et al., 2008), human resource practices (Wheeler et al., 2010) etc. to job embeddedness. However hardly any study has tried to link organizational identification with job embeddedness. This study attempts to build a case for linking organizational identification with job embeddedness within the frame work of "Social identity theory" (Ashforth \& Mael 1989, p. 20).

The study was undertaken with the following objectives. First, to explore the literature and build a case for linking two established construct namely organizational identification and job embeddedness. Second, to empirically examine this relationship in Indian context as not many studies involving the above constructs have been studied in the context of India. Third, to examine the role of perceived organizational support and job satisfaction with regard to the relationship between organizational identification and job embeddedness as perceived organizational support and job satisfaction are considered as antecedents and/or outcomes of 
organizational identification and job embeddedness (Ngo et al., 2013, Riketta, 2005, Sluss et al., 2008). Fourth, to provide inputs to the managers operating in India for dealing with the issue of employee turnover.

\section{Literature Review and Hypotheses Development}

\subsection{Definitions}

\subsubsection{Job Embeddedness}

Job embeddedness is measured from three dimensions-"links" with relevant others, "fit" with the environment concerned and the cost of "sacrificing" the "links" and the "fit", in the context of on- the job and off- the job situations (Mitchell, 2001, p. 1104).

\subsubsection{Organizational Identification}

Organizational identification is more of a "cognitive construct" (Mael \& Ashforth, 1992, p. 105) and it is defined as the "cognitive" connection (Dutton et al., 1994, p. 242) between the image an individual has about himself or herself and the image he or she has about his or her organization (Dutton, et al., 1994, p. 245).

\subsubsection{Job Satisfaction}

Job Satisfaction, is primarily defined as assessment of multiple features (co-workers, supervision, opportunities for growth etc.) of a job by an individual (Distel et al., 2014, p. 355),

\subsubsection{Perceived Organizational Support}

Perceived organizational support is defined as "global beliefs concerning the extent to which the organization values their employees' contributions and cares about their well-being" (Eisenberger et al., 1986, p. 501).

\subsection{Social Identity Theory}

Social identity theory argues that individuals delineate themselves based on their memberships of respective groups (Tajfel \& Turner, 1985). According to Ashforth and Meal (1989 pp. 20-21) this segregation helps individuals in "cognitively segment" themselves and also derive "personal and social identity" from their groups. Ashforth and Meal (1989, pp. 21-22) further argue that more an individual has "perception of oneness with or belongingness to some human aggregate" more will be that individual's "social identification" to that group and if the group in context is the organization then the "social identification" takes the form of "organizational identification".

\subsection{Correlates of Job Embeddedness}

Several studies have supported the negative relationships between Job embeddedness and turnover intention (for review see Jiang et al., 2012). Lee et al. (2004, p. 711) in their study found that off- the job embeddedness is a better predictor of "voluntary turnover" than on -the job embeddedness. Contrary to the findings of Lee et al. (2004), Dawley and Andrews (2012) reported that on -the job embeddedness is a better predictor of turnover intention and this relationship is moderated by off- the job embeddedness. However meta- analysis of the studies by Jiang, et al. (2012) revealed that both the constituents of job embeddedness (on-the job and off-the job) have been found to be playing a significant role in predicting turnover behavior (Jiang et al., 2012).

Though most of the studies have predominantly linked job embeddedness to turnover behavior, some studies have linked job embeddedness to other outcome variables such as citizenship behavior (Lee et al., 2004) performance (Halbasleben \& Wheeler, 2008) innovation (Ng \& Feldman, 2010) etc. Job embeddedness has also been found to be a moderator of positive link between leader member exchange and Organization Citizenship Behavior in a manner that higher the job embeddedness, stronger will be the relationship and lower the job embeddedness weaker will be the relationship (Sekiguchi et al., 2008)

Harris et al. (2011) reported that organizational job embeddedness mediated the relationship between leader member exchange and turnover behavior. Thus indicating that leader member exchange could be a possible predictor of organizational job embeddedness. Wheeler et al. (2010) posited that organizational job embeddedness mediated the relationship between human resource management effectiveness and turnover intention. In other words effective human resource management practices leads to higher organizational embeddedness, which in turn reduces the turnover intention. Lev (2012) reported that on- the job embeddedness was correlated significantly with extra role component of job performance and it mediated (partially) the link between conscientiousness and the extra role behavior, hinting that the personality attributes could also be predictors of job embeddedness. Ng and Feldman (2011, p. 186) argued that people with high Internal locus of control have high social networking behavior and could negotiate better employment benefits for themselves, these in turn results in higher organizational embeddedness for them. They also posited that personality traits 
may not be directly related to embeddedness but certain traits may play a role in helping people to obtain important resources of the organization, which may result in higher embeddedness $(2011$, p. 186). Based on a longitudinal study, Wille et al. (2010) reported that people low on Agreeableness were engaged more in job changing behavior (voluntary or involuntary). They suggested that this could be because for people who are low on agreeableness, breaking their ties with their co- workers is much easier (2010, p. 556). While individual traits influences an employee's job embeddedness, literature also suggests that, Co-workers' job embeddedness could also be an antecedent of individual employee's job embeddedness (Felps et al., 2009). Allen (2006, p. 237) posited that "socialization tactics" did influence job embeddedness among newcomers. "Socialization tactics" predicted, on-the job embeddedness which in-turn influenced voluntary turnover through affective commitment (Allen \& Shanock, 2013, p. 350).

Allen, D. G. (2006, p. 243) posited that members of an organization get embeddeded to the organization by bonding with other members through social interactions. These bonds could also lead to emotional attachment (affective commitment) to the organization. (Allen \& Shanock, 2013, p. 356).

\subsection{Organizational Identification and Job Embeddedness}

In the context of organizational behavior "social identity theory" provides the clarity as why and how concept like commitment is different from the concept of organizational identification (Ashforth \& Mael, 1989, p. 20). Organizational identification is "cognitive" in nature (Mael \& Ashforth, 1992, p. 105), whereas organizational commitment has more to do with behavior and "affect" (Mael \& Ashforth, 1992, p. 105). Also on the basis of "social identity theory" Ashforth and Mael (1989, p. 25) argued that personal interactions, closeness etc. are not necessarily important for organizational identification though they may facilitate organizational identity

Researchers over the years (since 1985) have treated organizational identity on the basis of seminal work of Albert and Whetten (1985), wherein they proposed that an organization derives its identity from the attributes which are "central, distinctive and enduring" (Gioia et al., 2000, p. 63).

Organizational identity has more to do with the image held by an individual about his/her organization and it is an outcome of an interactive process of negotiation between top management and internal as well external stakeholders (Scott \& Lane, 2000, p. 45). The top management plays a significant role in promoting images of the organization which are legitimate and attractive to the stakeholders (Scott \& Lane, 2000, p. 49).

Based on these images and other images of the organization, stakeholders associate an organization with certain characteristics and if large number of people identifies the organization with these characteristics, they contribute to the organizational reputation (Herrbach et al., 2004, p. 1391).

Hogg and Terry (2000, p. 123) posited that "Self-categorization theory" (an extension of self-identity theory) explains the phenomena of an individual's attempt to match the "prototype" of an organization by "depersonalization" of self. More attracted the members are to the "prototype" more will be the interaction and cohesion among the members leading to solidarity and more importantly greater identification (Hogg \& Terry, 2000, p. 126).

Scholars suggest that organizational identification in the realm of "social identity theory" is mainly through "distinctiveness and prestige" (Jones \& Volpe, 2011, p. 415) and not much through interactions and cohesion of members (Ashforth \& Mael, 1989, p. 25). However role of "interpersonal interactions" cannot be ignored while dealing with organizational identification (Jones \& Volpe, 2011, p. 426). The management's willingness to listen to an employee and providing him/her with an open and trustworthy "communication climate" improves Organizational identification (Smidts et al., 2001, p. 1053). "Network size", that is number of members an individual reaches out for advice and/or would like to be with to resolve personal issues, was found to be positively related with the strength of one's organizational identification (Jones \& Volpe, 2011, p. 420). Increased organizational identification among the employees will lead to more togetherness among the employees (Dutton et al., 1994, p. 254). Also it is reported that organizational identification induces more cooperation among the employees (Dukerich et al., 2002). Based on the above discussion it may be argued that organizational identification will prompt people to develop "links" within the organization.

Ashforth and Meal (1989, p. 27) argued that although "internalization" of organizational values etc. may happen irrespective of the level of organizational identification, the relationship between "socialization" and "internalization" is strengthen by organizational identification (1989, p. 29). Riketta (2005, p. 361) on the basis of his meta-analysis on organizational identification posited that one's fit with and acceptance of, the organizational values, practices etc. along with emotional attachment to the organization is linked to organizational identification. Hence people with stronger organizational identification will have better "fit" with 
the organization. Based on the above discussions it is argued that organizational identification influences development of "links" within the organization and also "fit" with the organization. Thus, the following hypothesis is proposed:

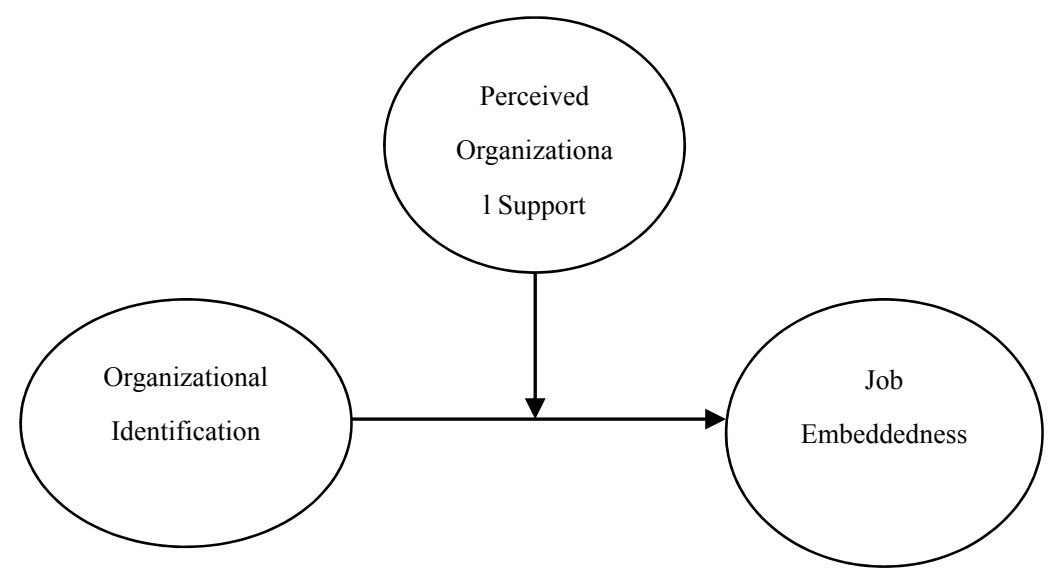

Figure 1.

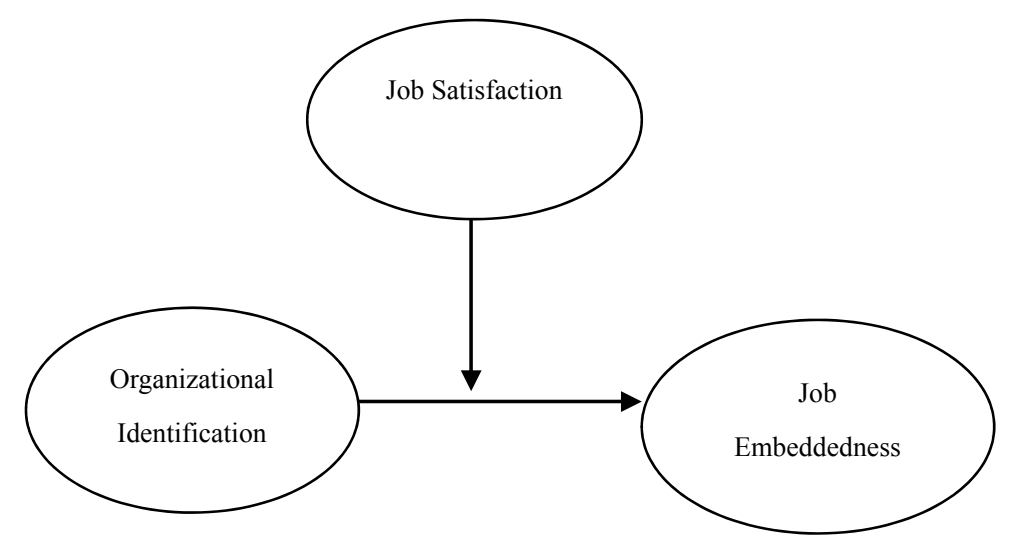

Figure 2.

\section{Hypothesis 1: Organizational identification is positively related to Job embeddedness.}

Job embeddedness has been widely used to predict turnover intention (Mitchell, 2001, p. 1103). Riketta (2005) reported that organizational identification correlates with job satisfaction. Van et al. (2004) nomologically and empirically argued that organizational identification results in job satisfaction which in turn influences turnover intention. Loi et al. (2014, p. 45) posited that good leader member exchange can lead to higher feeling of oneness with the organization which in turn results in better job satisfaction. Similarly (Ngo et al., 2013) reported that in collective cultures too, organizational identification was linked to job satisfaction positively. Van et al. (2004) reported that job satisfaction mediates the relationship between organizational identification and turnover intention. As both job satisfaction and job embeddedness are reported to be negatively related to turnover intention (Mitchell, 2001), it is argued that higher job satisfaction will positively strengthen the relationship between organizational identification and job embeddedness. Thus, it is hypothesized that:

Hypothesis 2: The relationship between organizational identification and job embeddedness will be moderated in such a manner that the relationship between organizational identification and job embeddedness will be stronger when job satisfaction is higher and the relationship will be weaker when job satisfaction is lower.

Role of perceived organizational support as an antecedent of organizational identification cannot be ignored (Meal \& Ashforth, 1992). Sluss et al. (2008) posited that organizational identification is positively influenced by perceived organizational support and also leader member exchange leads to perceived organizational support which in turn influences organizational identification. Their argument stems out of the logic that positive 
perceived organizational support is instrumental in inducing sense of "self-worth" and thereby "self enhancement" (2008, p. 459). Edwards and Peccei (2010) investigated the role of organizational identification as a mediator on the relationship between perceived organizational support and turnover intention and reported that the effect was significant. In another study, Edwards (2009) posited that human resource practices predicts organizational identification and it also feeds into perceived organizational support to predict organizational identification. Without undermining the role of perceived organizational support as an antecedent of organizational identification, in this study perceived organizational support is considered as a moderating variable and it is argued that:

Hypothesis 3: The relationship between organizational identification and job embeddedness will be moderated in such a manner that the relationship between organizational identification and job embeddedness will be stronger when perceived organizational support is higher and the relationship will be weaker when perceived organizational support is lower.

\section{Methods}

\subsection{Sample and Measures}

Self-reporting questionnaires were used to collect data from employees spread across various industries in India. Data was collected as a part of a larger study from the executives of various sectors such as consulting, healthcare, information technology etc., who attended management development programs at a leading business school in India and also from the alumni of the above mentioned business school. In all 325 usable responses were obtained. The respondents were assured that their responses will be kept confidential and will be used only for the purpose of academic research. Of the 325 usable responses, 77 percent of the respondents were males. Respondents who were less than 40 years of age constituted 76 percent of the sample. 35 percent of the respondents were having experience of 12 years or more and respondents who had 4 to 11 years of experience constituted 53 percent of the sample

\subsection{Measures}

\subsubsection{Job Embeddeness}

Job embeddedness was measured using the global measure proposed by Crossley et al. (2007, p. 1035). The scale had seven items. Each item was measured on a five point scale (1="strongly disagree" to $5=$ "strongly agree"). Sample items are "I am tightly connected to this organization; I feel attached to this organization".

\subsubsection{Organizational Identification}

Organizational identification was measured using the scale proposed by Mael and Ashforth, (1992, p. 122). The six item questionnaire had five point scale ( $1=$ "strongly disagree" to $5=$ "strongly agree"). Sample items are "When I talk about this organization, I usually say 'we' rather than 'they'; this organization's success are my success".

\subsubsection{Perceived Organizational Support}

Nine item scale proposed by Eisenberger et al. (1986, p. 502) which appeared in Fields, D. L. (2002, p. 118) was used for this study. Sample item are "The organization cares about my opinion"; "the organization really cares about my well- being".

\subsubsection{Job Satisfaction}

Three item measure on five point scale was used for the study (Mitchell et al., 2001). The sample item are "All in all I am satisfied with the job"; "In general I like working here".

\section{Results}

The table 1 provides the means, standard deviations and the correlations of the variables studied. The correlation between organizational identification and job embeddedness was positive and significant $(0.50, \mathrm{p}<0.01)$. The moderator variable job satisfaction was positively and significantly related to the organizational identification $(0.44, \mathrm{p}<0.01)$ and also to job embeddedness $(0.49, \mathrm{p}<0.01)$. The other moderator variable, perceived organizational support had significant positive relationship with organizational identification $(0.50, \mathrm{p}<0.01)$ and job embeddedness $(0.48, \mathrm{p}<0.01)$. Both the moderators were also positively related $(0.64, \mathrm{p}<0.01)$. The data was further analyzed using Hierarchical regression technique. In the first phase (Table 2) hypothesis 1 and hypothesis 2 were tested. Control variables, age and tenure were entered first. Next the independent variable and the moderator (in this case, job satisfaction) was entered. The standardized beta value of the relationship between organizational identification and job embeddedness $(B=0.34, p<0.01)$ signified support for hypothesis 1 . The 
model explained 35 percent variance. In the next stage interactive term (organizational identification $\mathrm{x}$ job satisfaction) was entered. The change in the $\mathrm{R}^{2}$ was non-significant. Thus revealing absence of moderation (Hair et al., 2003).

In the following phase (Table 3 ) the same process was repeated with another moderator namely perceived organizational support. The standardized beta value $(B=0.31, p<0.01)$ of the relationship between organizational identification and job embeddedness reinforced the support for the hypothesis 1.The model explained 35 per cent variance. Similar to earlier phase when the interactive term (organizational identification $x$ perceived organizational support) was entered, the change in the $\mathrm{R}^{2}$ was not significant. Hence like job satisfaction, perceived organizational support was also found not be moderating the relationship between organizational identification and job embeddedness.

Table 1. Descriptive statistics and correlations

\begin{tabular}{lllllllll}
\hline & Mean & $\begin{array}{l}\text { Standard } \\
\text { Deviation }\end{array}$ & $\mathbf{1}$ & $\mathbf{2}$ & $\mathbf{3}$ & $\mathbf{4}$ & $\mathbf{5}$ & $\mathbf{6}$ \\
\hline Age & 1.92 & .94 & 1 & $.83^{* *}$ & $.23^{* *}$ & $.25^{* *}$ & $.13^{*}$ & $.24^{* *}$ \\
Tenure & 3.95 & 2.26 & & 1 & $.21^{* *}$ & $.22^{* *}$ & $.13^{*}$ & $.23^{* *}$ \\
Organizational & 3.87 & .79 & & & 1 & $.50^{* *}$ & $.50^{* *}$ & $.44^{* *}$ \\
Identification & & & & & & $.48^{* *}$ & $.49^{* *}$ \\
Job Embeddedness & 3.21 & .77 & & & 1 & $.64^{* *}$ \\
Perceived & 3.51 & .86 & & & & & 1 \\
Organizational & & & & & & & \\
Support & & & & & & & \\
Job Satisfaction & 3.71 & .95 & & & & & & \\
\hline
\end{tabular}

** Significant at $0.01 ; *$ Significant at 0.05 .

Table 2. Regression analysis - 1 (job satisfaction as moderator)

Job Embeddedness

\begin{tabular}{llll}
\hline & $\begin{array}{l}\text { Model 1 } \\
\text { Standardized Beta }\end{array}$ & $\begin{array}{c}\text { Model 2 } \\
\text { Step 1: Control Variables }\end{array}$ & \\
Age & $.22^{*}$ & .10 & .10 \\
Tenure & .04 & -.00 & -.00 \\
Step 2: Independent and Moderating Variables & & & \\
Organizational Identification & $.34^{* *}$ & $.33^{* *}$ \\
Job Satisfaction & $.32^{* *}$ & $.31^{* *}$ \\
Step 3: Quantitative Effect & & \\
Organizational Identification X Job Satisfaction & & & -.04 \\
Overall Model & & & \\
$\mathrm{R}^{2}$ & .06 & .35 & .35 \\
$\Delta \mathrm{R}^{2}$ & & $.29^{* *}$ & .00 \\
\hline
\end{tabular}

** Significant at $0.01 ; *$ Significant at 0.05 . 
Table 3. Regression analysis -2 (perceived organization support as moderator)

Job Embeddedness

\begin{tabular}{lccc}
\hline & Model 1 & Model 2 & Model 3 \\
\hline Step 1: Control Variables & & & \\
Age & $.22^{*}$ & .13 & .13 \\
Tenure & .04 & .00 & .01 \\
Step 2: Independent and Moderating Variables & & & \\
Organizational Identification & $.31^{* *}$ & $.29^{* *}$ \\
Perceived Organization Support & $.30^{* *}$ & $.30^{* *}$ \\
Step 3: Quantitative Effect & & \\
Organizational Identification X Perceived Organizational Support & & & -.07 \\
Overall Model & & & \\
$\mathbf{R}^{2}$ & .06 & .35 & .35 \\
$\Delta \mathbf{R}^{2}$ & & $.28^{* *}$ & .00 \\
\hline
\end{tabular}

** Significant at $0.01 ; *$ Significant at 0.05 .

\section{Discussion}

This study was set out to link organizational identification with job embeddedness. Scanning through the literature, it was found that these two established constructs in main stream organizational behavior literature has not been empirically linked. Given that there are quite a few studies (Riketta, 2005; Van et al., 2004) which have explored the relationship between organizational identification and turnover intention and also the relationship between job embeddedness and turnover intention (Jiang et al., 2012) a theoretical framework was attempted to link organizational identification to job embeddedness. It was hypothesized that the relationship will be positive.

The study results reveal that as hypothesized a strong correlation was found between these two variables. In other words an employee who identifies himself/herself with the organization will develop more "links" within the organization as he/she considers himself/herself as a strong part of the organization as a whole. This strong connect with the organization makes him/her feel that his/her successes lies in the organization's success. As a result of this bond it becomes difficult for him/her to "sacrifice" the "links" developed within the organization and thereby he/she get embedded in the organization.

It was hypothesized that this positive relationship between organizational identification and job embeddedness will be further strengthen if the employee perceives strong support from the organization. Interestingly, this was not supported. Moreover it was also hypothesized that high job satisfaction will accentuate the positive relationship between organizational identification and job embeddedness. This hypothesis was also not supported.

These above findings are noteworthy. It implies that perceived organizational support and ones satisfaction with the job play insignificant roles when it comes job embeddedness emanating out of organizational identification. In other words if an employee has strong organizational identification then he/she will continue with the organization even if he/she perceives the organization to be less supportive or has he/she has low job satisfaction.

\subsection{Managerial Implications}

Organizations put in lot of efforts to retain employees. This study provides a few tips to the organizations for enhancing job embeddedness for possibly reducing turnover intentions. As the study reveals that identification with one's organization results in stronger job embeddedness, attempts should be made firstly to enhance the external prestige of the organization. Literature suggests that perceived external prestige is a strong antecedent of organizational identification (Smidts et al., 2001, p. 1052). This could be done by pertinent image building exercises. Secondly, the study builds a strong case for hiring people based on value congruence between the prospective employee and the organization, as this fasten the process of building strong identification with the organization (Scott \& Lane, 2000). Thirdly, a well-meaning socialization process of new employees should be put in place, as the literature reveals that socialization process helps in creating strong organizational identification (Ashforth \& meal, 1989).

The findings also provide a word of caution to the managers. High job embeddedness and strong organizational identification of the employees should not be taken as a measure for employee satisfaction. This view was further reinforced, when the researcher contacted some of the respondents and shared the findings with them. 
Some of the respondents did mention that they draw their identity from the organization and this identity do help in developing off the job "links" which in turn, embeds them to the job. Over a period of time it becomes difficult for them to "sacrifice" these "links" even if they don't find the organization a conducive place to work. Hence it is recommended that managers from time to time should gauge employee satisfaction through surveys or meetings. This will help in taking corrective steps to ensure motivated workforce.

\subsection{Limitations and Future Direction of Research}

Being a cross sectional study, causal relationship between the variables cannot be established. Moreover, generalizability of the findings could also be a limitation though efforts have been made to collect data from various industries across different cities of India. Given the interesting findings, that the perceived organization support and also job satisfaction play insignificant role in strengthening the relationship between organizational identification and job embeddedness, it will be worthwhile to replicate the study in different situations and also use longitudinal approach to establish causal relationship.

\section{Conclusion}

This study attempted to link organizational identification to job embeddedness as the literature is silent on this relationship though there are evidences to theoretically link them. Hence data was collected and analyzed to empirically test this relationship. The findings suggested that these two variables are strongly related signifying that organizational identification is a strong predictor of job embeddedness. The findings also revealed that job satisfaction and perceived organizational support which are also predictors of job embeddedness did not moderate the relationship between organizational identification and job embeddedness.

\section{References}

Albert, S., \& David, A. W. (1985). Organizational identity. In Larry L. Cummings., \& Barry M. Staw (Eds.), Research in organizational behavior. An Annual Series of Analytical Essays and Critical Reviews, 263-295. Greenwich: JAI Press.

Allen, D. G. (2006). Do organizational socialization tactics influence newcomer embeddedness and turnover? Journal of Management, 32(2), 237-256. http://dx.doi.org/10.1177/0149206305280103

Allen, D. G., \& Shanock, L. R. (2013). Perceived organizational support and embeddedness as key mechanisms connecting socialization tactics to commitment and turnover among new employees. Journal of Organizational Behavior, 34(3), 350-369. http://dx.doi.org/10.1002/job.1805

Ashforth, B. E., \& Mael, F. (1989). Social identity theory and the organization. Academy of Management Review, 14(1), 20-39. http://dx.doi.org/10.5465/AMR.1989.4278999

Bauer, T. N., Erdogan, B., Liden, R. C., \& Wayne, S. J. (2006). A longitudinal study of the moderating role of extraversion: Leader-member exchange, performance, and turnover during new executive development. Journal of Applied Psychology, 91(2), 298-310. http://dx.doi.org/10.1037/0021-9010.91.2.298

Blau, P. (1964). Exchange and power in social life. New York: Wiley.

Carmeli, A. (2005). Perceived external prestige, affective commitment, and citizenship behaviors. Organization Studies, 26(3), 443-464. http://dx.doi.org/10.1177/0170840605050875

Chen, G., Ployhart, R. E., Thomas, H. C., Anderson, N., \& Bliese, P. D. (2011). The power of momentum: A new model of dynamic relationships between job satisfaction change and turnover intentions. Academy of Management Journal, 54(1), 159-181. http://dx.doi.org/10.5465/AMJ.2011.59215089

Crossley, C. D., Bennett, R. J., Jex, S. M., \& Burnfield, J. L. (2007). Development of a global measure of job embeddedness and integration into a traditional model of voluntary turnover. Journal of Applied Psychology, 92(4), 1031-1042. http://dx.doi.org/10.1037/0021-9010.92.4.1031

Dawley, D. D., \& Andrews, M. C. (2012). Staying Put Off-the-Job Embeddedness as a Moderator of the Relationship Between On-the-job Embeddedness and Turnover Intentions. Journal of Leadership \& Organizational Studies, 19(4), 477-485. http://dx.doi.org/10.1177/1548051812448822

De Cuyper, N., Mauno, S., Kinnunen, U., \& Mäkikangas, A. (2011). The role of job resources in the relation between perceived employability and turnover intention: A prospective two-sample study. Journal of vocational behavior, 78(2), 253-263. http://dx.doi.org/10.1016/j.jvb.2010.09.008

Diestel, S., Wegge, J., \& Schmidt, K. (2014). The Impact of Social Context on the Relationship between Individual Job Satisfaction and Absenteeism: The Roles of Different Foci of Job Satisfaction and Work-unit Absenteeism. Academy of Management Journal, 57(2), 353-382. http://dx.doi.org/10.5465/amj.2010.1087 
Direnzo, M. S., \& Greenhaus, J. H. (2011). Job search and voluntary turnover in a boundaryless world: A control theory perspective. Academy of Management Review, 36(3), 567-589. http://amr.aom.org/content/36/3/567.short

Dukerich, J. M., Golden, B. R., \& Shortell, S. M. (2002). Beauty is in the eye of the beholder: The impact of organizational identification, identity, and image on the cooperative behaviors of physicians. Administrative Science Quarterly, 47(3), 507-533. http://dx.doi.org/10.2307/3094849

Dutton, J. E., Dukerich, J. M., \& Harquail, C. V. (1994). Organizational images and member identification. Administrative Science Quarterly, 239-263.

Edwards, M. R. (2009). HR, perceived organisational support and organisational identification: An analysis after organisational formation. Human Resource Management Journal, 19(1), 91-115. http://dx.doi.org/10.1111/j.1748-8583.2008.00083.x

Edwards, M. R., \& Peccei, R. (2010). Perceived organizational support, organizational identification, and employee outcomes: Testing a simultaneous multifoci model. Journal of Personnel Psychology, 9(1), 17-26. http://dx.doi.org/10.1027/1866-5888/a000007

Eisenberger, R., Huntington, R., Hutchison, S., \& Sowa, D. (1986). Perceived organizational support. Journal of Applied Psychology, 71(3), 500-507. http://dx.doi.org/10.1037/0021-9010.71.3.500

Felps, W., Mitchell, T. R., Hekman, D. R., Lee, T. W., Holtom, B. C., \& Harman, W. S. (2009). Turnover contagion: How coworkers' job embeddedness and job search behaviors influence quitting. Academy of Management Journal, 52(3), 545-561. http://dx.doi.org/10.5465/AMJ.2009.41331075

Fields, D. L. (2002). Taking the measure of work: A guide to validated scales for organization research and diagnosis. http://dx.doi.org/10.4135/9781452231143.n1

Gioia, D. A., Schultz, M., \& Corley, K. G. (2000). Organizational identity, image, and adaptive instability. Academy of management Review, 25(1), 63-81. http://dx.doi.org/10.5465/AMR.2000.2791603

Griffeth, R. W., Hom, P. W., \& Gaertner, S. (2000). A meta-analysis of antecedents and correlates of employee turnover: Update, moderator tests, and research implications for the next millennium. Journal of Management, 26(3), 463-488. http://dx.doi.org/10.1177/014920630002600305

Hair Jr., J. F., Anderson, R. E., Tatham, R. L., \& Black, W. C. (2003). Multivariate data analysis. India: Pearson.

Halbesleben, J. R., \& Wheeler, A. R. (2008). The relative roles of engagement and embeddedness in predicting job performance and intention to leave. Work \& Stress, 22(3), 242-256. http://dx.doi.org/10.1080/02678370802383962

Harris, K. J., Wheeler, A. R., \& Kacmar, K. M. (2011). The mediating role of organizational job embeddedness in the LMX-outcomes relationships. The Leadership Quarterly, 22(2), 271-281. http://dx.doi.org/10.1016/j.leaqua.2011.02.003

Herrbach, O., Mignonac, K., \& Gatignon, A. L. (2004). Exploring the role of perceived external prestige in managers' turnover intentions. The International Journal of Human Resource Management, 15(8), 1390-1407. http://dx.doi.org/10.1080/0958519042000257995

Hogg, M. A., \& Terry, D. I. (2000). Social identity and self-categorization processes in organizational contexts. Academy of Management Review, 25(1), 121-140. http://dx.doi.org/10.5465/AMR.2000.2791606

Hom, P. W., Tsui, A. S., Wu, J. B., Lee, T. W., Zhang, A. Y., Fu, P. P., \& Li, L. (2009). Explaining employment relationships with social exchange and job embeddedness. Journal of Applied Psychology, 94(2), 277-297. http://dx.doi.org/10.1037/a0013453

Jiang, K., Lepak, D. P., Hu, J., \& Baer, J. C. (2012). How does human resource management influence organizational outcomes? A meta-analytic investigation of mediating mechanisms. Academy of Management Journal, 55(6), 1264-1294. http://dx.doi.org/10.5465/amj.2011.0088

Jiang, K., Liu, D., McKay, P. F., Lee, T. W., \& Mitchell, T. R. (2012). When and how is job embeddedness predictive of turnover? A meta-analytic investigation. Journal of Applied Psychology, 97(5), 1077-1096. http://dx.doi.org/10.1037/a0028610

Jones, C., \& Volpe, E. H. (2011). Organizational identification: Extending our understanding of social identities through social networks. Journal of Organizational Behavior, 32(3), 413-434. http://dx.doi.org/10.1002/job.694 
Lee, T. W., Mitchell, T. R., Sablynski, C. J., Burton, J. P., \& Holtom, B. C. (2004). The effects of job embeddedness on organizational citizenship, job performance, volitional absences, and voluntary turnover. Academy of Management Journal, 47(5), 711-722. http://dx.doi.org/10.2307/20159613

Lev, S., \& Koslowsky, M. (2012). On-the-job embeddedness as a mediator between conscientiousness and school teachers' contextual performance. European Journal of Work and Organizational Psychology, 21(1), 57-83. http://dx.doi.org/10.1080/1359432X.2010.535656

Loi, R., Chan, K. W., \& Lam, L. W. (2014). Leader-member exchange, organizational identification, and job satisfaction: A social identity perspective. Journal of Occupational and Organizational Psychology, 87(1), 42-61. http://dx.doi.org/10.1111/joop.12028

Mael, F., \& Ashforth, B. E. (1992). Alumni and their alma mater: A partial test of the reformulated model of organizational identification. Journal of organizational Behavior, 13(2), 103-123. http://dx.doi.org/10.1002/job.4030130202

March, J. G., \& Simon, H. A. (1958). Organizations. New York: John Wiley and sons.

Mitchell, T. R., Holtom, B. C., Lee, T. W., Sablynski, C. J., \& Erez, M. (2001). Why people stay: Using job embeddedness to predict voluntary turnover. Academy of Management Journal, 44(6), 1102-1121. http://dx.doi.org/10.2307/3069391

Ng, T. W., \& Feldman, D. C. (2010). The impact of job embeddedness on innovation - related behaviors. Human Resource Management, 49(6), 1067-1087. http://dx.doi.org/10.1002/hrm.20390

Ng, T. W., \& Feldman, D. C. (2011). Locus of control and organizational embeddedness. Journal of $\begin{array}{llll}\text { Occupational and } & \text { Organizational }\end{array}$ http://dx.doi.org/10.1348/096317910X494197

Ngo, H. Y., Loi, R., Foley, S., Zheng, X., \& Zhang, L. (2013). Perceptions of organizational context and job attitudes: The mediating effect of organizational identification. Asia pacific journal of management, 30(1), 149-168. http://dx.doi.org/10.1007/s10490-012-9289-5

Riketta, M. (2005). Organizational identification: A meta-analysis. Journal of Vocational Behavior, 66(2), 358-384. http://dx.doi.org/10.1016/j.jvb.2004.05.005

Scott, S. G., \& Lane, V. R. (2000). A stakeholder approach to organizational identity. Academy of Management Review, 25(1), 43-62. http://dx.doi.org/10.5465/AMR.2000.2791602

Sekiguchi, T., Burton, J. P., \& Sablynski, C. J. (2008). The role of job embeddedness on employee performance: The interactive effects with leader member exchange and organization based self-esteem. Personnel Psychology, 61(4), 761-792. http://dx.doi.org/10.1111/j.1744-6570.2008.00130.x

Sluss, D. M., Klimchak, M., \& Holmes, J. J. (2008). Perceived organizational support as a mediator between relational exchange and organizational identification. Journal of Vocational Behavior, 73(3), 457-464. http://dx.doi.org/10.1016/j.jvb.2008.09.001

Smidts, A., Pruyn, A. T. H., \& Van Riel, C. B. (2001). The impact of employee communication and perceived external prestige on organizational identification. Academy of Management Journal, 44(5), 1051-1062. http://dx.doi.org/10.2307/3069448

Tejfel, H., \& Turner, J. C. (1985). The social identity theory of intergroup behavior. In S. Worchel \& W.G. Austin (Eds.), Psychology of intergroup relations (2nd ed., pp. 7-24). Chicago: Nelson-Hall.

Van Dick, R., Christ, O., Stellmacher, J., Wagner, U., Ahlswede, O., Grubba, C. Hauptmeier, M., Höhfeld, C., Moltzen, K., \&Tissington, P. A. (2004). Should I stay or should I go? Explaining turnover intentions with organizational identification and job satisfaction. British Journal of Management, 15(4), 351-360. http://dx.doi.org/10.1111/j.1467-8551.2004.00424.x

Wheeler, A. R., Harris, K. J., \& Harvey, P. (2010). Moderating and Mediating the HRM Effectiveness--Intent to Turnover Relationship: The Roles of Supervisors and Job Embeddedness. Journal of Managerial Issues, 22(2). Retrieved from http://www.jstor.org/stable/20798904

Wille, B., De Fruyt, F., \& Feys, M. (2010). Vocational interests and Big Five traits as predictors of job instability. Journal of Vocational Behavior, 76(3), 547-558. http://dx.doi.org/10.1016/j.jvb.2010.01.007 


\section{Note}

Note 1. www.thehindubusinessline.com/.../india...employee-turnover.../article47

\section{Copyrights}

Copyright for this article is retained by the author(s), with first publication rights granted to the journal.

This is an open-access article distributed under the terms and conditions of the Creative Commons Attribution license (http://creativecommons.org/licenses/by/3.0/). 